\section{Comparison of antianginal actions of verapamil and propranolol}

Verapamil is a slow calcium channel blocker that has been in clinical use for almost 20 years as an antiarrhythmic agent. It also has an antianginal action, ${ }^{1}$ but inconsistent results have been obtained in clinical trials owing to insufficient dosage. ${ }^{2}$ We found that the drug produced a significant decrease in the number of anginal attacks and the consumption of glyceryl trinitrate with improvement in exercise tolerance and ST changes when used in a dose of $360 \mathrm{mg}$ daily. ${ }^{3}$ We have now compared the potency and mode of action of verapamil with those of propranolol, a standard beta-adrenergicreceptor-blocking drug, using fixed high doses of each.

\section{Patients, methods, and results}

Twenty-two patients (age range 41-69 years) with confirmed chronic stable angina completed a double-blind cross-over trial designed as a direct objective comparison between verapamil and propranolol in which exercise data were measured. ${ }^{4}$ After a two-week run-in period when they took a placebo the patients were treated over four-week periods with verapamil $120 \mathrm{mg}$ thrice daily or propranolol $80 \mathrm{mg}$ thrice daily (at 0800 , 1400 , and 2000).

Exercise tests on a treadmill (Quinton) were repeated after the placebo and each treatment period (90-150 minutes after the last dose of the drug). The tests were performed in a temperature-controlled laboratory and stopped when the patient developed angina or could not continue owing to fatigue, dyspnoea, or claudication. Electrocardiographic monitoring was performed using a mini-computer system, and the protocol was identical throughout the trial. ${ }^{3}$ Two bipolar leads (CM5 and CC5) were continuously recorded with 25-beat averaging during and after exercise, and the values for heart rate, ST-segment levels, and ectopic counts were printed out every minute. At the end of each test a continuous trend plot was evolved for each variable. The ST-segment level was measured at the J point in relation to the PR interval. Standards as outlined by the American Heart Association were observed throughout. ${ }^{5}$ Statistical analysis was performed using Student's $t$ test (two-tailed). The table shows the variables calculated.

Both drugs were well tolerated with few side effects. Constipation was a constant feature with verapamil and tiredness or lethargy with propranolol. Four patients became free of angina with propranolol and 10 with verapamil. Propranolol improved the exercise time by $40 \%$; its primary effect appeared to be to reduce heart rate (resting heart rate was reduced by $26 \%$ and maximum exercise heart rate by $23 \%$ ). The heart rate recovery was not altered. The maximum ST-segment depression corrected for exercise time was significantly reduced $(p<0.001)$. Verapamil had a different effect: it reduced the resting heart rate by only $6.5 \%$ and the maximal exercise heart rate by $3 \%$. The heart rate recovery was not altered. The maximum ST-segment change remained the same. The exercise time, however, increased by $66 \%$, and the maximum heart rate and ST depression-seen during placebo treatment at 5.5 minutes-now occurred at 9.1 minutes. These figures suggest an improved exercise tolerance with no adverse effect on ischaemia. ST-segment recovery was also unchanged.

\section{Comment}

Verapamil has little negative chronotropic effect but improves exercise tolerance more than propranolol, probably because of decreased coronary vasomotion and improved myocardial oxygen consumption. On the other hand, propranolol seems to act predominantly through its negative chronotropic effect. These observa- tions are important to clinicians. Patients with resting bradycardia and a poor chronotropic response to exercise would be expected to respond better to verapamil, while those with resting tachycardia and an appreciable chronotropic response to exercise would respond better to propranolol. These observations have obvious practical implications in choosing treatment rationally.

VBS is supported by a grant from the British Heart Foundation.

${ }^{1}$ Parodi O, Maseri A, Simonetti I. Management of unstable angina at rest by verapamil: a double blind cross-over study in coronary care unit. Br Heart f 1979;41:167-74.

${ }^{2}$ Herxheimer A. Claims for Cordilox. Drug Ther Bull 1967;5:85-7.

3 Subramanian VB, Paramasivan R, Lahiri A, Raftery EB. Verapamil in chronic stable angina: a controlled study with computerised multistage treadmill exercise. Lancet 1980;i:841-4.

${ }^{4}$ Sheffield LT. Quantitative approach to exercise testing for ischaemic heart disease. In: Snellen HA, ed. Quantitation in cardiology. Netherlands: Leiden University Press, 1972.

${ }^{5}$ Ellestad MH, Chairman MD, Blomqvist CG, Naughton JP. Standards for adult exercise testing laboratories. Circulation 1979;58:421-30A.

(Accepted 19 March 1981)

Cardiac Department and Division of Clinical Sciences, Northwick Park Hospital and Clinical Research Centre, Harrow, Middlesex HA1 3UJ

M J BOWLES, MRCP, honorary registrar

V BALA SUBRAMANIAN, MD, FACC, consultant clinical physiologist

A B DAVIES, MRCP, honorary senior registrar

E B RAFTERY, MD, FRCP, consultant cardiologist

\section{Colonisation of ventriculoatrial shunt with Brucella abortus}

Bacterial colonisation of ventriculoatrial shunts is a well-recognised complication with a reported incidence as high as $24 \% .^{1}$ The organisms most commonly isolated are coagulase-negative staphylococci (Staphylococcus albus). Although other organisms-for example, diphtheroids and Bacillus species-have been isolated, ${ }^{2}$ ventriculoatrial shunt colonisation with Brucella species has not been reported. We report such a case.

\section{Case report}

A 4-month-old boy with hydrocephalus secondary to aqueductal stenosis underwent uneventful placement of a right ventriculoatrial shunt using a Holter valve. At the age of 5 years he was admitted to this hospital with a two-month history of lethargy, vomiting, headache, and fever. Physical examination showed an irritable, poorly nourished child with a temperature of $39^{\circ} \mathrm{C}$. The upper part of the valve was exposed owing to skin necrosis. Liver and spleen were palpable $4 \mathrm{~cm}$ below the costal margin. He lived in a rural area and his father was a farmer. Cows' milk produced on the farm was sometimes consumed in the home.

Laboratory investigations showed haemoglobin $9.7 \mathrm{~g} / \mathrm{dl}$ and white cell count $6.4 \times 10^{9} / 1$ (differential count neutrophils $37 \%$, lymphocytes $61 \%$, and

\begin{tabular}{|c|c|c|c|c|c|c|}
\hline & \multirow[b]{2}{*}{ Placebo } & \multirow[b]{2}{*}{$\begin{array}{l}\text { Propranolol } \\
(240 \mathrm{mg})\end{array}$} & \multirow[b]{2}{*}{$\begin{array}{l}\text { Verapamil } \\
\text { (360 mg) }\end{array}$} & \multicolumn{3}{|c|}{ Significance (p) } \\
\hline & & & & $\begin{array}{c}\text { Placebo } \\
v \\
\text { propranolol }\end{array}$ & $\begin{array}{c}\text { Placebo } \\
v \\
\text { verapamil }\end{array}$ & $\begin{array}{c}\text { Propranolol } \\
v \\
\text { verapamil }\end{array}$ \\
\hline $\begin{array}{l}\text { Exercise time (min) } \\
\text { Resting heart rate (beats } / \mathrm{min}) \\
\text { Maximum heart rate (beats/min) } \\
\text { Heart rate recovery at } 5 \mathrm{mins}(\text { beat } / \mathrm{min})^{*} \\
\text { Maximum ST depression }(\mathrm{mm}) \text { in } \mathrm{CM} 5 \\
\text { Maximum ST depression }(\mathrm{CM} 5) / \text { exercise time }(\mathrm{mm} / \mathrm{min}) \\
\text { ST recovery at } 5 \text { mins in CM5 }(\mathrm{mm})\end{array}$ & $\begin{aligned} 5 \cdot 5 & \pm 0 \cdot 4 \\
76 & \pm 3 \\
135 & \pm 3 \\
51 & \pm 2 \\
2 \cdot 4 & \pm 0 \cdot 2 \\
0 \cdot 48 & \pm 0 \cdot 06 \\
1 \cdot 9 & \pm 0 \cdot 2\end{aligned}$ & $\begin{aligned} 7 \cdot 8 & \pm 0 \cdot 5 \\
56 & \pm 2 \\
104 & \pm 3 \\
39 & \pm 2 \\
1 \cdot 7 & \pm 0 \cdot 1 \\
0 \cdot 24 & \pm 0 \cdot 03 \\
1 \cdot 3 & \pm 0 \cdot 1\end{aligned}$ & $\begin{array}{l}9 \cdot 1 \pm 0 \cdot 5 \\
71 \pm 3 \\
130 \pm 3 \\
50 \pm 2 \\
2 \cdot 2 \pm 0 \cdot 2 \\
0 \cdot 28 \pm 0 \cdot 04 \\
1 \cdot 4=0 \cdot 2\end{array}$ & $\begin{array}{l}<0.001 \\
<0.001 \\
<0.001 \\
<0.001 \\
<0.01 \\
<0.001 \\
<0.01\end{array}$ & $\begin{array}{l}<0.001 \\
<0.01 \\
\text { NS } \\
\text { NS } \\
\text { NS } \\
<0.001 \\
<0.01\end{array}$ & $\begin{array}{l}<0.01 \\
<0.001 \\
<0.001 \\
<0.001 \\
\text { NS } \\
\text { NS } \\
\text { NS }\end{array}$ \\
\hline
\end{tabular}

*Heart rate recovery is the difference between maximum exercise values and values five minutes after exercise. 
monocytes $2 \%$ ). Direct aspiration of the shunt reservoir yielded clear cerebrospinal fluid, which on examination showed white cell count $0.01 \times 10^{9} / 1$, protein $0.35 \mathrm{~g} / 1$, and glucose $3.8 \mathrm{mmol} / 1(68 \mathrm{mg} / 100 \mathrm{ml})$. The cerebrospinal fluid showed Gram-negative pleomorphic bacilli. Multiple blood cultures were obtained, and he was started on gentamicin and cloxacillin. Four days after admission the infected shunt was removed; a striking clinical improvement followed. Cultures of cerebrospinal fluid, blood, and shunt all yielded a growth of $\mathrm{Br}$ abortus biotype 2 . Serological tests for brucellosis were set up immediately after the cerebrospinal fluid and blood culture results became available. The titre in the saline agglutination test was $1 / 80$, antihuman globulin test $1 / 1280$, and complement fixation test $1 / 64$. Blood samples were obtained from members of his family for serological investigation for brucellosis. The table summarises the results.

By the age of 7 he was asymptomatic and without hepatosplenomegaly. His hydrocephalus had been arrested, and the shunt had not had to be replaced.

Results of bacteriological and serological tests carried out on patient's family

\begin{tabular}{|c|c|c|c|c|}
\hline $\begin{array}{c}\text { Family } \\
\text { member }\end{array}$ & $\begin{array}{l}\text { Blood } \\
\text { culture }\end{array}$ & $\begin{array}{c}\text { Saline } \\
\underset{\text { agglutination }}{\text { test }}\end{array}$ & $\begin{array}{c}\text { Antihuman } \\
\text { globulin } \\
\text { test }\end{array}$ & $\begin{array}{c}\text { Complement } \\
\text { fixation } \\
\text { test }\end{array}$ \\
\hline $\begin{array}{l}\text { Father } \\
\text { Mother } \\
\text { Sibling } 1 \\
\text { Sibling } 2 \\
\text { Sibling } 3\end{array}$ & $\begin{array}{l}\text { No growth } \\
\text { No growth } \\
\text { No growth } \\
\text { No growth } \\
\text { No growth }\end{array}$ & $\begin{array}{l}1 / 160 \\
1 / 20 \\
1 / 20 \\
1 / 80 \\
1 / 20\end{array}$ & $\begin{array}{l}1 / 320 \\
1 / 80\end{array}$ & $\begin{array}{l}\bar{z} \\
\bar{z}\end{array}$ \\
\hline
\end{tabular}

\section{Comment}

Ventriculoatrial shunt colonisation has been described as "early" when the symptoms appear two or three months after operation and "late" when the patient remains symptom free for several months or even years after operation. ${ }^{3}$ The early cases have been shown to originate at operation, when bacteria normally present on the skin become implanted at the site of the operation and subsequently colonise the shunt. Late colonisation has been attributed to ascending colonisation from the tip of the atrial catheter after transient bacteremia. ${ }^{4}$ Both types of colonisation have recently been shown to have the same aetiology, however, the onset of bacterial colonisation of the shunt occurring at operation. ${ }^{35}$

Most cases of brucellosis in man result from direct contact with sick animals or ingestion of unpasteurised milk from infected animals. Our patient had animal contacts in an area where bovine brucellosis is a problem. He had also taken unpasteurised cows' milk on severa occasions. The infecting organism appears to have entered the shun and the cerebrospinal fluid from the blood stream after septicaemia caused by $\mathrm{Br}$ abortus.

Treatment in shunt colonisation consists of removing the shunt and replacing it when the cerebrospinal fluid is sterile. In brucellosis the treatment of choice is tetracycline. Our patient was initially given antibiotics directed against the organism (Staph albus) most commonly responsible for shunt colonisation, and the infected shunt was subsequently removed. By the time culture results had become available the cerebrospinal fluid and blood were sterile and he had shown a remarkable clinical recovery without having been treated specifically for brucellosis.

We thank Mr Barry O'Donnell for permission to report this case. We are greatly indebted to Dr L R Hill of the Central Public Health Laboratory, Colindale, and Dr D J H Payne of the Public Health Laboratory, Portsmouth, for identifying the strains.

${ }^{1}$ Puri P, Dorner S, Eckstein HB. The results of treatment of hydrocephalus with the Holter valve: a six to eighteen year follow up. Zeitschrift für Kinderchirurgie und Grenzgebiete 1977;22:14-23.

2 Welch K. The prevention of shunt infection. Zeitschrift für Kinderchirurgie und Grenzgebiete 1977;22:465-75.

${ }^{3}$ Bayston R, Lari J. A study of the sources of infection in colonised shunts. Dev Med Child Neurol 1974; suppl 32:16-21.

${ }^{4}$ Holt RJ. Bacteriological studies on colonised ventriculoatrial shunts. Dev Med Child Neurol 1970; suppl 22:83-7.

${ }^{5}$ Bayston R, Spitz L. The role of retrograde movement of bacteria in ventriculoatrial shunt colonisation. Zeitschrift für Kinderchirurgie und Grenzgebiete 1978;25:352-6.

(Accepted 25 February 1981)

Children's Research Centre, Our Lady's Hospital for Sick Children, Crumlin, Dublin 12, Ireland

P PURI, MS, associate paediatric surgeon

$T$ W HARVEY, FIMLS, senior technologist, microbiology

\section{Ketotifen overdose: surveillance of the toxicity of a new drug}

Self-poisoning is often with drugs that have been selected indiscriminately by the patient with no knowledge of their effects. ${ }^{1}$ Hence doctors may be faced with overdoses of new and unfamiliar compounds for which there is little information on the likely symptoms or the most appropriate treatment. Such advice as can be offered is usually based on extrapolation from toxicity studies in animals and from clinical experience with other, similar drugs, but the value of such information is questionable.

A recent example of this was provided by the introduction of the antiasthmatic drug ketotifen (Zaditen, Sandoz Limited), a selective mast-cell stabiliser with many features of an antihistamine. Through the National Poisons Information Service effective surveillance of the acute toxicity of a new compound can be monitored from the first recorded cases. Within four months of ketotifen being marketed eight cases of overdose had been reported and a reasonable estimate could be made of the acute toxicity of the drug in man.

\section{Summary of cases}

The table gives brief details of the eight cases. Gastric lavage was used in six patients, one (case 5) was given syrup of ipecacuanha, and in case 6 no attempt was made to empty the stomach. All eight patients received supportive treatment only and made a full recovery within 12 hours of admission. Toxicological screens were performed at the poisons unit and plasma ketotifen concentrations measured by Sandoz, Basle Limited, using mass spectrometry after gas chromatographic separation. ${ }^{2}$

Details of eight cases of overdose with ketotifen

\begin{tabular}{|c|c|c|c|c|c|}
\hline Case No & $\underset{\text { (years) }}{\text { Age }}$ & Sex & $\begin{array}{c}\text { Stated } \\
\text { ingested } \\
\text { dose }(\mathrm{mg})\end{array}$ & Symptoms & Comments \\
\hline 1 & 27 & $\mathrm{~F}$ & 20 & $\begin{array}{l}\text { Confused, brady- } \\
\text { cardia }\end{array}$ & \\
\hline 2 & 21 & F & 120 & $\begin{array}{l}\text { Mild abdominal } \\
\text { pain, headache }\end{array}$ & $\begin{array}{l}\text { Plasma concentration } \\
\text { of ketotifen-base } \\
122 \mathrm{mg} / 1 \text { 20 hours } \\
\text { after ingestion. } \\
\text { Negative drug } \\
\text { screen }\end{array}$ \\
\hline 3 & 34 & $M$ & 40 & $\begin{array}{l}\text { Drowsy, brady- } \\
\quad \text { cardia, confused }\end{array}$ & $\begin{array}{l}\text { Plasma concentration } \\
\text { of ketotifen }-5 \mathrm{mg} / 1 \\
\text { two hours after } \\
\text { ingestion. Negative } \\
\text { drug screen }\end{array}$ \\
\hline 4 & 23 & F & 60 & $\begin{array}{l}\text { Drowsy, nystagmus, } \\
\text { tachypnoea }\end{array}$ & \\
\hline 5 & 6 & $\mathrm{~F}$ & 10 & $\begin{array}{c}\text { Drowsy, dis- } \\
\text { orientated, } \\
\text { nystagmus, } \\
\text { tachypnoea, } \\
\text { tachycardia }\end{array}$ & $\begin{array}{l}\text { Negative drug screen. } \\
\text { Plasma concentra- } \\
\text { tion of ketotifen } \\
16 \mathrm{mg} / 1 \text { five hours } \\
\text { after ingestion }\end{array}$ \\
\hline 6 & 18 & $\mathrm{~F}$ & 25 & $\begin{array}{l}\text { Drowsy, grand-mal } \\
\text { convulsions, } \\
\text { depressed } \\
\text { respiratory rate, } \\
\text { tachycardia }\end{array}$ & \\
\hline 7 & 21 & $\mathbf{M}$ & 50 & $\begin{array}{l}\text { Unconscious on } \\
\text { admission; } \\
\text { recovered } \\
\text { consciousness in } \\
\text { two hours }\end{array}$ & $\begin{array}{l}\text { Negative drug screen. } \\
\text { Plasma concentra- } \\
\text { tion of ketotifen } \\
54 \mathrm{mg} / 1 \text { three hours } \\
\text { after ingestion }\end{array}$ \\
\hline 8 & 20 & $\mathrm{~F}$ & 60 & $\begin{array}{c}\text { Drowsy, confused, } \\
\text { bradycardia }\end{array}$ & \\
\hline
\end{tabular}

\section{Comment}

Studies of the toxicity of ketotifen in animals suggested that likely symptoms of overdosage in man would include drowsiness, confusion, dyspnoea, cyanosis, tachycardia, hyperexcitability and convulsions. The predicted symptoms were quite accurate, although their severity appeared to be less than that initially expected. The experimental studies also suggested that induced diuresis could be of value. So far however, such treatment has not been needed.

Monitoring the clinical presentation and outcome in alleged drug overdosage can provide useful information, ${ }^{3}$ but before the toxicity of a compound can be assessed with any certainty it is important to prove that the drug concerned was present in toxic amounts. Therapeutic plasma concentrations of ketotifen range from 1 to $4 \mathrm{mg} / \mathrm{l}$. Thus case 3 is typical of many patients who patently did not take the dose of the drug which was claimed, while in case 2 the patient had definitely 